\title{
Pemanfaatan Aplikasi Canva Untuk Desain Grafis Dan Promosi Produk Pada Sekolah Islami Berbasis Kewirausahaan
}

\author{
Fenty Fahminnansih ${ }^{1}$, Endra Rahmawati², Ayouvi Poerna Wardhanie ${ }^{3 *}$ \\ 1,2,3 Fakultas Teknologi dan Informatika, Universitas Dinamika \\ e-mail: $\underline{\text { fenty@dinamika.ac.id }}$, $\underline{\text { rahmawati@dinamika.ac.id }}^{2}, \underline{\text { ayouvi@dinamika.ac.id }}^{3}$ \\ *Penulis Korespondensi: E-mail: ayouvi@dinamika.ac.id
}

\begin{abstract}
The rapid development of the digital world today, of course, has an impact on all areas of people's lives, for example in the fields of education and business. Everything that was previously done offline has now turned online, as well as the competencies that a teacher must have in providing learning to students in the classroom. Roudlotul Banat as an entrepreneurship-based Islamic school is very aware that improving the skills of teachers in terms of graphic design and product promotion using applications that are currently trending is very important. Therefore, in this Community Service activity, a training will be held entitled Using Canva Applications for Graphic Design and Product Promotion at Islamic Schools Based on Entrepreneurship. The method used before conducting the training was by observing and interviewing the needs of the teachers to the teacher representatives appointed by the principal, then socializing the activities and agreeing on the training time. The success indicators of this training are adding insight related to online learning media, motivation to use online learning media, and increasing the creativity and competence of teachers. The result of this activity is an evaluation of training in the use of Canva's online design application, which is distributed through a questionnaire to the trainee teachers. The results of the questionnaire state that this training can add new insights and improve skills/creativity in developing learning materials in the classroom. With this training, it is hoped that it can improve the skills of teachers regarding the use of applications that are currently popular with students, according to the needs of learning in the classroom.
\end{abstract}

Keywords: Canva, Entrepreneurship, Graphic Design, Promotion, Online.

\begin{abstract}
Abstrak
Pesatnya dunia digital saat ini, tentunya sangat berimbas pada segala bidang kehidupan masyarakat, contohnya saja dalam bidang pendidikan dan bisnis. Semua hal yang tadinya dilakukan secara offline kini berubah menjadi online, begitu juga kompetensi yang harus dimiliki oleh seorang guru dalam memberikan pembelajaran pada siswa di kelas. Roudlotul Banat sebagai sekolah islami berbasis kewirausahaan sangat menyadari bahwa peningkatan ketrampilan guru dalam hal desain grafis dan promosi produk dengan menggunakan aplikasi yang sedang trend saat ini sangatlah penting. Oleh sebab itu, pada kegiatan Pengabdian Masyarakat ini akan dilakukan pelatihan yang bertajuk Pemanfataan Aplikasi Canva untuk Desain Grafis dan Promosi Produk Pada Sekolah Islami Berbasis Kewirausahaan. Metode yang dilakukan sebelum melakukan pelatihan adalah dengan observasi dan wawancara terkait kebutuhan guru-guru kepada perwakilan guru yang ditunjuk oleh Kepala Sekolah, kemudian melakukan sosialisasi kegiatan dan kesepatakan waktu pelatihan. Adapun indikator keberhasilan dari pelatihan ini yaitu menambah wawasan terkait media pembelajaran online, motivasi penggunaan media pembelajaran online, dan meningkatkan daya kreativitas dan kompetensi guru. Hasil dari kegiatan ini adalah evaluasi pelatihan dalam penggunaan aplikasi desain online Canva, yang disebar melalui kuesioner kepada para guru peserta pelatihan. Hasil kuesioner menyebutkan bahwa pelatihan ini dapat menambah wawasan baru dan meningkatkan ketrampilan/kreativitas dalam mengembangkan materi pembelajaran di kelas. Dengan adanya pelatihan ini diharapkan dapat meningkatkan ketrampilan para guru terkait pemanfaatan aplikasi yang sedang digemari oleh para siwa saat ini, sesuai dengan kebutuhan pembelajaran di kelas.
\end{abstract}


Kata Kunci: Aplikasi Canva, Kewirausahaan, Desain Grafis, Promosi, online.

\section{PENDAHULUAN}

Seiring dengan perkembangan ilmu pengetahuan dari masa ke masa, berkembang pula teknologi-teknologi baru yang menandai adanya kemajuan zaman, hingga kini terknologi yang berkembang tengah memasuki ke dalam dunia serba digital (Sumarno \& Gimin, 2019). Pesatnya dunia digital dan internet tersebut, tentu juga berimbas pada segala bidang diantaranya adalah bidang pendidikan dan bisnis, yang mana tren ke dua bidang saat ini beralih dari yang semula konvensional (offline) menjadi digital (online) (Purwana, Rahmi, \& Aditya, 2017). Dalam dunia pendidikan, teknologi digital sudah mulai digunakan untuk mendukung proses pembelajaran, baik sebagai alat informasi atau sebagai sarana penunjang kegiatan belajar dan tugas (Lestari, 2018), sedangkan dalam dunia bisnis, teknologi dapat menjamin kelancaran dan optimisasi layanan ke pelanggan serta meningkatkan kinerja suatu perusahaan (Irnawati, 2015).

Dalam mendukung program pemerintah dalam memenuhi tuntutan era industri 4.0 dalam bidang bisnis atau kewirausahaan, Sekolah Roudlotul Banat - Taman, Sidoarjo yang merupakan sekolah yang dirancang khusus untuk membimbing siswa-siswinya dengan bekal ilmu pengetahuan agama, umum, dan entrepreneur menginginkan adanya pengembangan kompetensi guru dalam hal desain grafis dan promosi produk dengan memanfaatkan aplikasi atau teknologi yang sedang trend saat ini, guna menunjang proses pembelajaran di sekolah (Sarwa, 2019). Pengurus MA Roudlotul Banat - Taman, Sidoarjo menyadari bahwa guru-guru di sekolah tersebut masih membutukan kemampuan yang lebih up to date dalam bidang desain grafis/poster, mengingat sekolah ini memiliki semboyan sebagai Sekolah Islami Berbasis Kewirausahaan. (Adawiyah, Hasanah, \& Munsi, 2019) menyebutkan bahwa proses pembelajaran perlu diselaraskan dengan kemajuan zaman dan kebutuhan para pembelajar yang merupakan generasi milenial. Generasi milenial atau generasi visual ini perlu didekati dengan stimulus yang mudah untuk diterima dan dilaksanakan (Modalku, 2019). Stimulus yang paling menarik perhatian adalah memberikan pembelajaran yang mendekati kebiasaan mereka, yaitu bermain gawai (teknologi dalam gawai) yang dikaitkan dengan pembelajaran. Selain itu, media visual sudah menjadi bagian dalam proses komunikasi manusia, sehingga diharapkan akan lebih mudah menstimulus daya kognitif siswa/siswi dalam pembelajaran (Hasan, M. (2018).

Aplikasi Canva merupakan salah satu media yang dapat mendukung proses pembelajaran secara visual dan melatih kemampuan literasi visual siwa (Adawiyah, Hasanah, \& Munsi, 2019). Canva merupakan program design online yang menyediakan berbagai alat editing untuk membuat berbagai desain grafis, seperti poster, flyer, infografik, banner, kartu undangan, presentasi, sampul Facebook, dan yang lainnya, termasuk menjadi alat dalam mengedit foto karena terdapat photo editor, photo filters, photo frame, stickers, icon, dan desain grids, mudah dipahami meskipun masih pemula. Tak hanya itu, Canva juga dapat diakses melalui perangkat desktop maupun mobile. Dengan demikian, pengguna dapat berkreasi kapan pun dan di mana pun (Nayoan, 2019). Dengan uraian pada latar belakang, maka dapat diidentifikasi permasalahan yang dihadapi mitra yaitu: [1] Pengembangan kompetensi guru dalam hal desain grafis dan promosi produk dengan memanfaatkan aplikasi atau teknologi yang sedang trend saat ini, yaitu Canva, [2] Memberikan pembelajaran yang mendekati kebiasaan dan kesukaan siswa, yaitu bermain gawai / teknologi, dan [3] Menstimulus daya kognitif siswa/siswi dalam pembelajaran melalui media visual. 


\section{METODE PELAKSANAAN}

Metode pelaksanaan dalam kegiatan pelatihan pemanfaatan aplikasi Canva kepada sekolah Islami berbasis Kewirausahaan secara garis besar dapat dilihat pada gambar 1 dibawah ini:

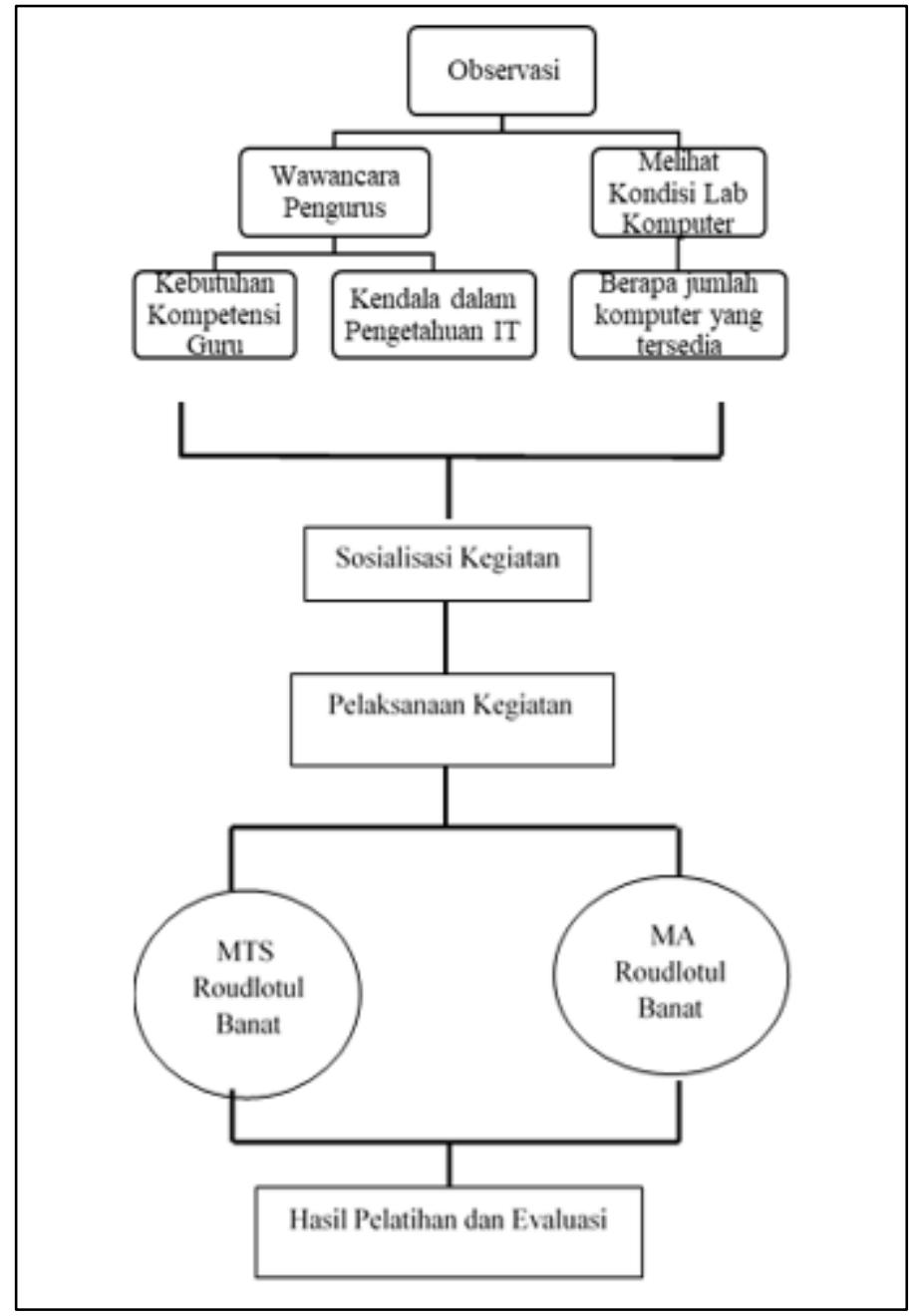

Gambar 1. Metode Pelaksanaan PKM

Pada mulanya, peneliti melakukan observasi dengan mendatangai MTS dan MA Roudlotul Banat Sidoarjo untuk melakukan wawancara kepada pengurus yayasan dan melihat bagaimana kondisi kesiapan laboratorium komputer yang ada di sekolah tersebut. Dalam proses wawancara tersebut, peneliti mencoba mengidentifikasi terkait kebutuhan kompetensi guru dan kendala tentang teknologi informasi yang dialami oleh para pengajar, sedangkan dalam observasi kondisi laboratorium komputer, peneliti ingin mengetahui berapa jumlah komputer yang tersedia dan dapat digunakan untuk melakukan pelatihan nanti. Setelah proses obervasi selesai dan diperoleh kesepakata antara pihak peneliti dengan yayasan, maka proses selanjutnya akan dilakukan sosialisasi kegiatan kepada seluruh guru atau pengajar yang telah ditentukan oleh pihak yayasan. Pada proses pelaksanaan kegiatan, peserta dalam pelatihan ini terdiri atas dua sekolah yang berada dibawah naungan yayasan yaitu MTS Roudlotul Banat dan MA Roudlotul Banat. Hasil dari pelatihan kepada kedua sekolah tersebut, akan menjadi evaluasi bagi peneliti untuk kesempurnaan program -program pelatihan serupa di masa yang akan datang. 


\section{HASIL dan PEMBAHASAN}

Pelatihan Aplikasi Canva: Pelatihan yang dilaksanakan pada kegiatan pengabdian masyarakat ini bersifat online, dengan jumlah peserta 26 guru MTS dan 22 guru MA. Pelatihan ini dilaksanakan secara online karena adanya pandemi Covid-19 yang melanda Indonesia, bahkan diseluruh dunia. Oleh sebab itu, pelatihan yang awalnya akan dilakukan dengan tatap muka, maka harus dilakukan secara tatap maya melalui aplikasi Google Meet, namun hal tersebut tidak mengurangi antusias dan semangat para guru-guru di MTS dan MA Roudlotul Banat, Taman Sidoarjo dalam meningkatkan ketrampilan dan penguasaan dalam menggunakan aplikasi desain online, Canva, seperti yang terlihat pada gambar dibawah ini:

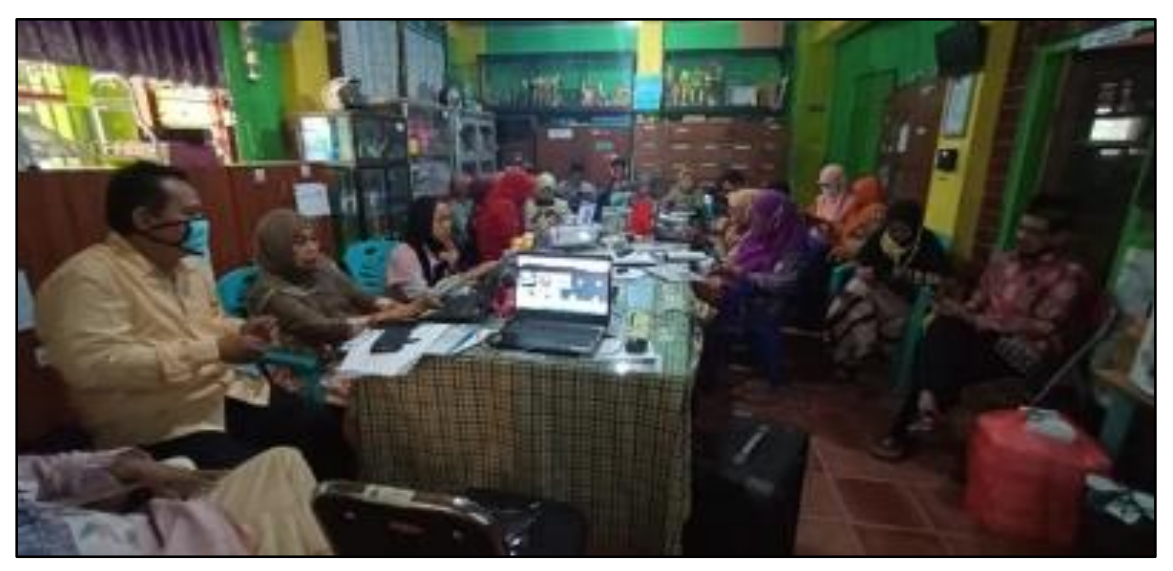

Gambar 2. Pelatihan Online Aplikasi Canva

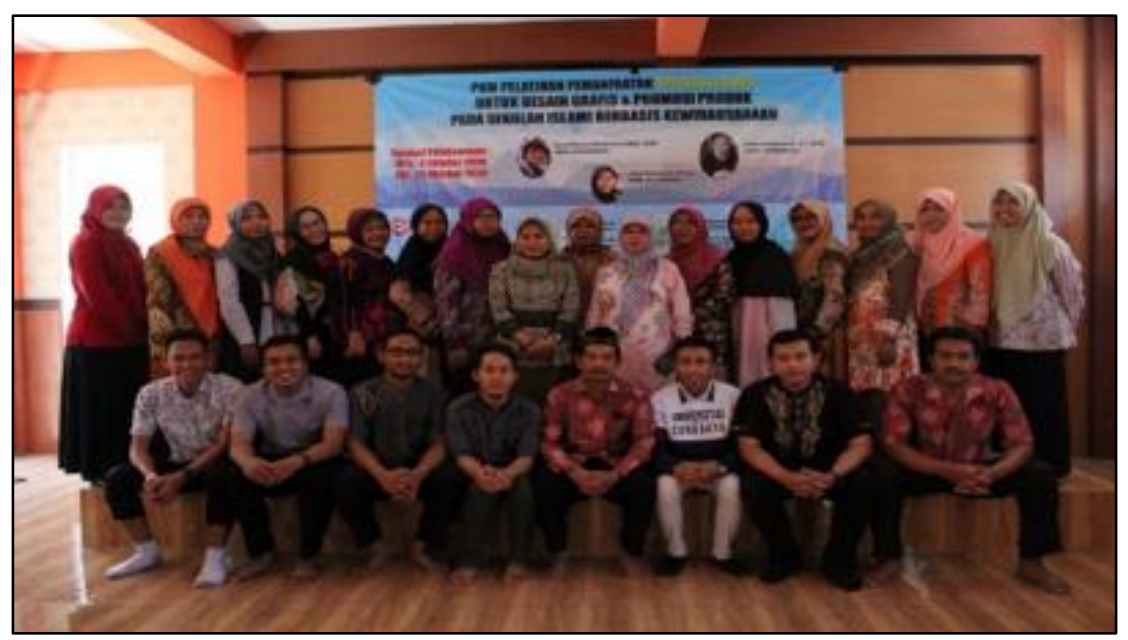

Gambar 3. Peserta Pelatihan dari MTS Roudlotul Banat 


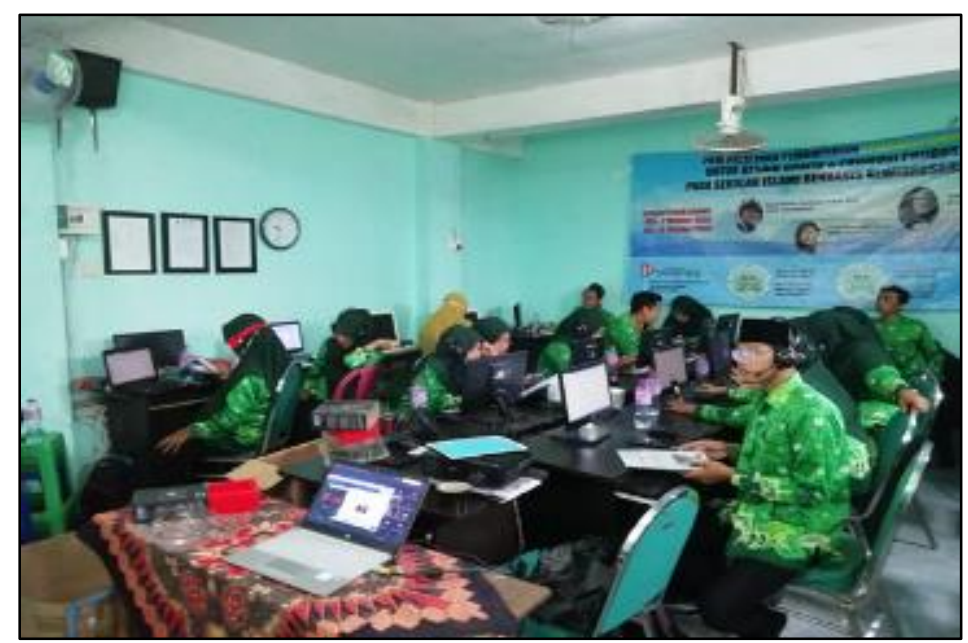

Gambar 4. Peserta Pelatihan dari MTS Roudlotul Banat

Adapun jadwal pelatihan dapat dilihat pada tabel 1 dibawah ini:

Tabel 1. Jadwal Pelatihan

\begin{tabular}{|c|c|c|c|c|}
\hline No & Kegiatan & Waktu & & Link \\
\hline 1 & $\begin{array}{l}\text { Pelatihan Pemanfaatan Aplikasi } \\
\text { Canva untuk guru - guru MTS } \\
\text { Roudlotul Banat }\end{array}$ & $\begin{array}{l}2 \text { Oktober } \\
\text { Pukul } 08.00 \\
\text { WIB }\end{array}$ & $\begin{array}{l}2020 \\
-\quad 11\end{array}$ & $\begin{array}{l}\text { meet.google.com/jfg-xjkv- } \\
\text { kfs }\end{array}$ \\
\hline 2 & $\begin{array}{l}\text { Pelatihan Pemanfaatan Aplikasi } \\
\text { Canva untuk guru - guru MTS } \\
\text { Roudlotul Banat }\end{array}$ & $\begin{array}{l}20 \text { Oktober } \\
\text { Pukul } 08.00 \\
\text { WIB }\end{array}$ & $\begin{array}{l}2020 \\
-\quad 11\end{array}$ & $\begin{array}{l}\text { Meet.google.com/res- } \\
\text { qypc-fpj }\end{array}$ \\
\hline
\end{tabular}

\section{Hasil yang Telah Dicapai}

Hasil yang diharapkan dari kegiatan PKM ini adalah dapat membantu pihak sekolah, khususnya guru-guru pengajar di sekolah Roudlotul Banat untuk dapat memanfaatkan penggunaan media desain online, Canva dalam membuat poster, flyer, logo dan lain sebagainya guna mendukung ilmu kewirausahaan serta dapat meningkatkan minat belajar siswa di kelas karena adanya bantuan media visual. Adapun hasil karya poster yang telah dikerjakan oleh beberapa peserta latihan adalah sebagai berikut:

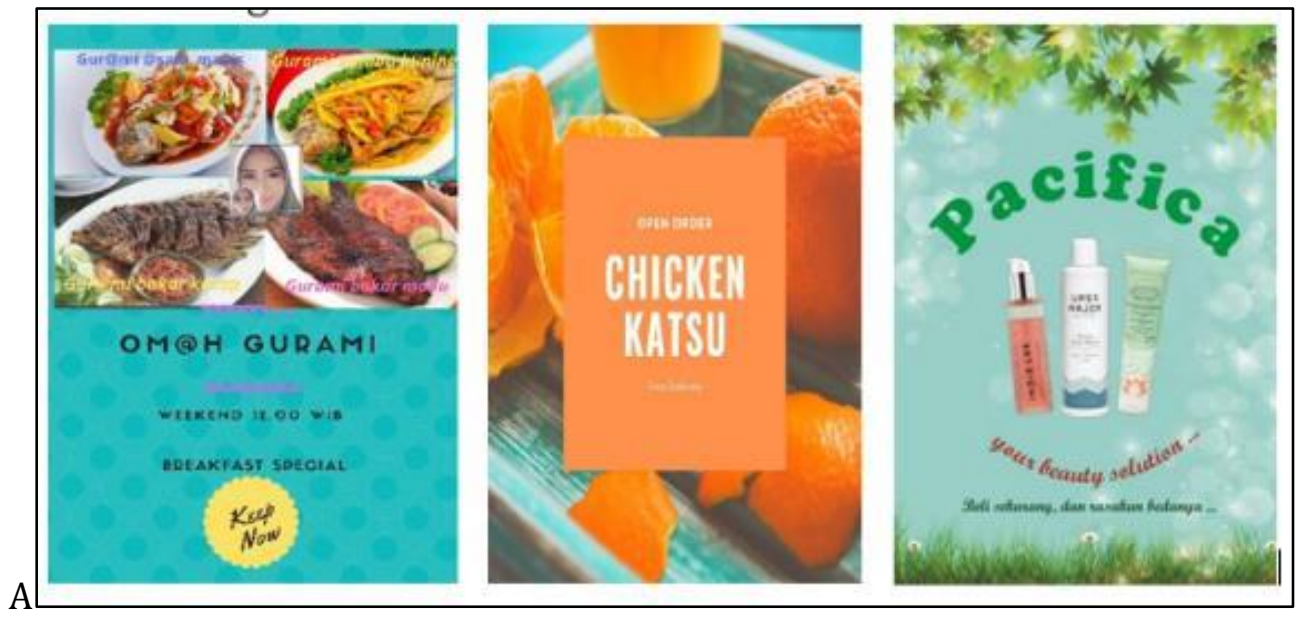


Dalam pelaksanaan pengabdian masyarakat ini, indikator ketercapaian yang diharapkan dari kegiatan ini adalah [1] dapat menambah wawasan baru bagi peserta, [2] memotivasi guru dalam memanfaatkan aplikasi sebagai media pembelajaran online, dan [3] meningkatkan kreativitas dan kompetensi guru dalam mengajar. Berdasarkan hasil kuesioner yang telah disebar ke peserta pelatihan online, didapatkan hasil seperti yang terlihat pada tabel 2 dan tabel 3 dibawah ini:

Tabel 2. Hasil Kuesioner MTS Roudlotul Banat

\begin{tabular}{|c|c|c|}
\hline No & Pertanyaan & Penilaian \\
\hline 1. & Pelatihan ini menambah wawasan baru & $88 \%$ \\
\hline 2. & $\begin{array}{l}\text { Aplikasi ini menambah motivasi guru dalam } \\
\text { menggunakan media pembelajaran online }\end{array}$ & $85 \%$ \\
\hline 3. & $\begin{array}{l}\text { Pemateri menjelaskan dengan jelas dan mudah } \\
\text { dipahami }\end{array}$ & $84 \%$ \\
\hline 4. & Pelatihan ini meningkatkan kreativitas & $89 \%$ \\
\hline 5. & Fasilitas dan jaringan internet memadai & $78 \%$ \\
\hline 6. & $\begin{array}{l}\text { Fitur pada aplikasi Canva memudahkan dalam } \\
\text { pembuatan poster }\end{array}$ & $83 \%$ \\
\hline 7. & $\begin{array}{l}\text { Banyak hal yang dapat lebih dieksplore dengan aplikasi } \\
\text { Canva }\end{array}$ & $87 \%$ \\
\hline 8. & Aplikasi ini mudah digunakan & $88 \%$ \\
\hline 9. & $\begin{array}{l}\text { Pelatihan ini meningkatkan profesionalisme dan } \\
\text { kompetensi }\end{array}$ & $87 \%$ \\
\hline 10. & $\begin{array}{l}\text { Perlu diadakan pelatihan lanjutan dengan topik } \\
\text { berbeda }\end{array}$ & $86 \%$ \\
\hline
\end{tabular}

Menurut hasil penilaian kuesioner diatas, terlihat bahwa perolehan presentase terbesar yaitu $89 \%$ terkait bahwa pelatihan ini dapat meningkatkan kreativitas, dan diikuti sebesar 88\% menyatakan bahwa pelatihan ini dapat menambah wawasan baru dan aplikasi yang diajarkan yaitu Canva merupakan aplikasi yang mudah digunakan. Sedangkan perolehan presentase terendah yaitu $78 \%$ terkait pada fasilitas internet dan jaringan di sekolah tersebut.

Tabel 3. Hasil Kuesioner MA Roudlotul Banat

\begin{tabular}{clc}
\hline No & \multicolumn{1}{c}{ Pertanyaan } & Penilaian \\
\hline 1. & Pelatihan ini menambah wawasan baru & $73 \%$ \\
2. & Aplikasi ini menambah motivasi guru dalam & $63 \%$ \\
& menggunakan media pembelajaran online & \\
3. & Pemateri menjelaskan dengan jelas dan mudah dipahami & $66 \%$ \\
4. & Pelatihan ini meningkatkan kreativitas & $71 \%$ \\
5. & Fasilitas dan jaringan internet memadai & $61 \%$ \\
6. & Fitur pada aplikasi Canva memudahkan dalam & $70 \%$ \\
& pembuatan poster & $67 \%$ \\
7. & Banyak hal yang dapat lebih dieksplore dengan aplikasi & \\
8. & Canva & $65 \%$ \\
9. & Pplikasi ini mudah digunakan & $67 \%$ \\
10. & kelatihan ini meningkatkan profesionalisme dan & $66 \%$ \\
\hline
\end{tabular}


Menurut hasil kuesioner peserta pelatihan sebanyak 22 orang yang berasal dari MA Roudlotul Banat, dapat dilihat bahwa perolehan presentase terbesar yaitu 73\% terkait dengan pelatihan ini dapat menambah wawasan baru, sedangkan hasil presentase terendah sebanyak $61 \%$ terkait pada fasilitas dan jaringan internet di sekolah tersebut.

\section{Asumsi Penilaian:}

Tabel 4. Asumsi Penilaian

\begin{tabular}{cc}
\hline $0-26$ & Sangat Buruk \\
$27-52$ & Buruk \\
$53-78$ & Baik \\
$79-104$ & Sangat Baik \\
\hline
\end{tabular}

Adapun Asumsi Hasil Penilaian Akhir terhadap perhitungan kuisioner pelatihan, dapat dikategorikan menjadi 4 skala interval. Untuk hasil 0-26\% menyatakan bahwa hasil pelatihan Sangat Buruk atau jauh dari harapan peserta. Untuk hasil 27\%-52\% menyatakan bahwa hasil melatihan masih Buruk dan tidak seperti harapan peserta. Sedangkan untuk skala prosentase 53\%-78\% menyatakan bahwa pelatihan sudah Baik atau Layak sesuai dengan harapan peserta. Apalagi dengan prosentase antara 79\%-100\% menyatakan bahwa pelatihan ini Sangat Baik dan sangat sesuai dengan harapan peserta.

Berdasarkan hasil perhitungan kuesioner Pelatihan Online Aplikasi Canva untuk Desain Grafis dan Promosi Produk pada kedua sekolah tersebut, dapat diambil kesimpulan bahwa rata-rata peserta di MTS Roudlotul Banat memberikan rata-rata 85.5\% respon sangat baik terhadap pelatihan ini dibandingkan dengan peserta yang berasal dari MA Roudlotul Banat yang hanya berada pada kisaran 66,9\% atau dapat dikatan cukup baik. Sebagian besar responden atau peserta pelatihan menyatakan bahwa pelatihan yang diadakan seperti ini dapat meningkatkan wawasan baru mereka, namun disisi lain, responden masih belum terasa puas dengan fasilitas dan jaringan internet selama mengikuti pelatihan tersebut.

\section{KESIMPULAN}

Adapun beberapa hal penting yang telah dihasilkan adalah sebagai berikut :

1. Pelatihan ini mampu memperkenalkan penggunaan teknologi yang sedang trend saat ini yaitu aplikasi Canva kepada para peserta pelatihan yaitu guru di MA dan MTS Roudlotul Banat untuk menunjang pembelajaran siswa di bidang Kewirausahaan khususnya dalam hal desain grafis dan promosi produk.

2. Pelatihan ini juga mampu memberikan suatu wawasan dan ketrampilan baru bagi para guru di MA dan MTS Roudlotul Banat dimana hal tersebut sesuai dengan kesukaan atau gaya hidup para siswa di zaman ini, yaitu bermain gawai/gadget.

3. Adanya pelatihan seperti ini, dapat membantu para guru-guru di kelas khususnya mata kuliah Kewirausahaan dalam menstimulus para siswa agar lebih sering melakukan praktik secara langsung dengan menggunakan bantuan media visual.

\section{UCAPAN TERIMAKASIH}

Penulis mengucapkan terima kasih kepada Lembaga Penelitian dan Pengabdian Masyarakat Universitas Dinamika Surabaya atas pendanaan hibah internal PKM Tahun 
Anggaran 2020 dan Kepala Sekolah dan Guru di Sekolah Islami berbasis Kewirausahaan, MTS dan MA Roudlotul Banat, Taman - Sidoarjo.

\section{DAFTAR PUSTAKA}

Adawiyah, A., Hasanah, A., \& Munsi, M. F. (2019). Literasi Visual Melalui Teknologi Canva : Stimulasi Kemampuan Kreativitas Berbahasa Indonesia Mahasiswa. Proceeding Education Transformation in Facing Industrial Revolution 4.0, 183.

Direktorat Pembinaan SMA, Direktorat Jenderal Pendidikan Dasar dan Menengah, K. (2019). Pedoman Program Kewirausahaan SMA. Jakarta.

Hasan, M. (2018). Pembinaan Ekonomi Kreatif Dalam Perspektif Pendidikan Ekonomi. JEKPEND: Jurnal Ekonomi Dan Pendidikan, 1(1), 81. https://doi.org/10.26858/jekpend.v1i1.5063

Irnawati. (2015). Peranan Teknologi Informasi dalam Meningkatkan Sistem Pemasaran. Faktor Exacta, 8(1): 14-22.

Lestari, S. (2018). Peran Teknologi Dalam Pendidikan di Era Globalisasi. Jurnal Pendidikan Agama Islam (edureligia), Vol. 2, No. 2, Juli - Desember .

Modalku. (2019). Peluang Ekonomi Kreatif Menghadapi Revolusi Industri 4. modalku. Retrieved from https://blog.modalku.co.id/bisnis/dunia-bisnis/peluang-ekonomikreatif-menghadapi-revolusi-industri-4-0/

Nayoan, A. ( 2019, November 29). Cara Menggunakan Canva: Tutorial Membuat Design Gratis. Retrieved from Niagahoster: https://www.niagahoster.co.id/blog/caramenggunakan-canva/

Purwana, D., Rahmi, \& Aditya, S. (2017). Pemanfaatan Digital Marketing Bagi Usaha Mikro, Kecil dan Menengah (UMKM) di Kelurahan Malaka Sari, Duren Sawit. Jurnal Pemberdayaan Masyarakat Madani (JPMM), Vol. 1 No. 1 Juli .

Sarwa. (2019). Pengembangan Teknopreneurship untuk Mata Pelajaran Produk Kreatif dan Kewirausahaan dalam Implementasi Kurikulum SMK Revisi 2016. In Seminar Nasional Asosiasi Pendidikan Teknologi dan Kejuruan Indonesia (p. 2018).

Sumarno, \& Gimin. (2019). Analisis Konseptual Teoretik Pendidikan Kewirausahaan Sebagai Solusi Dampak Era Industri 4.0 di Indonesia. Jurnal Pendidikan Ekonomi, 13, 1-14. https://doi.org/10.19184/jpe.v13i2.12557 